\title{
ANALISIS PENERAPAN STRATEGI BERTAHAN PIZZA HUT INDONESIA \& KONDISI LABA PERIODE BERJALAN SELAMA PANDEMI COVID-19
}

\author{
Hijrah Wahyudi \\ yudihwy.hw@gmail.com \\ STIE Indonesia Pontianak \\ Mardiyati \\ myathie_yd@gmail.com \\ STIE Pontianak
}

\begin{abstract}
This research is expected to be useful for stakeholders both theoretically and practically in terms of choosing and implementing a survival strategy in order to save the company, especially in times of crisis. To answer the research questions, qualitative data analysis techniques were used which followed the following three stages: Data analysis, drawing conclusions and verification and narrative of analysis results. It can be concluded that the defensive strategy undertaken by PT Sarimelati Kencana, Tbk in the face of the Covid-19 pandemic is appropriate, because it is proven that this strategy can still print positive sales, stable cost of goods sold, positive gross profit, still operating profit positive, and stable operating expenses. However, interest and financial expenses that exceed operating profit are the cause of losses for the franchise holder of the Pizza Hut Indonesia restaurant.From this research, it can be suggested for business people in general to consider and pay careful attention to plans or debt decisions. If the business actor is already in debt, then strengthen the intention and determination to immediately pay off these debts. Good products, good product selling prices, effective promotions, strategic selling locations, and increased sales volume will be in vain when business actors are faced with debt interest expenses that exceed operating profit.

Key word: survival strategy, Pizza Hut Indonesia, Covid-19 pandemic
\end{abstract}

\section{PENDAHULUAN}

\section{Latar belakang penelitian}

Pandemi virus corona atau COVID-19 telah berdampak negatif pada banyak bisnis waralaba di Indonesia, salah satunya yaitu waralaba makanan cepat saji (fast food). Dampak negatif yang utama ialah kesulitan dalam memenuhi target perusahaan yaitu volume penjualan produk yang merosot drastis. Persoalan tersebut juga dialami oleh salah satu bisnis waralaba terkemuka di Indonesia, yaitu PT Sarimelati Kencana, Tbk selaku pemegang hak waralaba tunggal Pizza Hut Indonesia.

Menghadapi situasi yang semakin sulit, Pizza Hut Indonesia menerapkan strategi untuk mempertahankan bisnis. Strategi bertahan yang dilakukan oleh Pizza Hut Indonesia, meliputi: berjualan pizza dengan harga promosi di pinggir jalan, berjualan pizza dengan konsep Wahana Foodtruck, dan menambah jumlah gerai penjualan pizza.
Adapun tujuan dari strategi yang dilakukan oleh Pizza Hut Indonesia, yaitu untuk semakin mendekatkan diri kepada konsumen yang diharapkan dapat mendongkrak volume penjualan.

Berikut ini merupakan beberapa kegiatan berjualan pizza dengan harga promosi di pinggir jalan yang dilakukan oleh Pizza Hut Indonesia selama pandemi Covid-19 di beberapa kota di Indonesia:

- Yogyakarta (Mei 2020) memperlihatkan sebuah sepeda motor dengan box pizza serta seorang karyawan yang melayani pembelian dengan ramah. (Nurhadi, 2020)

- Jakarta (Mei 2020) pizza tersebut ditawarkan menggunakan mobil atau motor dengan menampilkan banner-banner promo. Gerai pizza pinggir jalan itu juga dijaga oleh karyawan yang mengenakan seragam lengkap. (Fitria, 2020) 
- Makassar (2020) karyawan Pizza Hut menawarkan harga promo kepada pengguna jalan di Jl Ahmad Yani, Makassar. Sepinya pengunjung akibat Pembatasan Sosial Berskala Besar (PSBB) di Makassar, disiasati Pizza Hut dengan melakukan aksi jualan di pinggir jalan sebagai upaya bertahan di tengah pandemi virus Corona COVID-19. (Junior, 2020)

- Pontianak (Juni 2020) dengan memberikan keterangan bahwa promo funt4stic box Rp 100 ribu 4 box personal pizza tersebut hanya tersedia di layanan take-away di mana konsumen datang langsung ke gerai Pizza Hut untuk membeli paket promo Pizza Hut terbaru ini. (Ishak, 2020)

- Temanggung (Agustus 2020) mobil resmi Pizza Hut yang nangkring di depan kantor pusat kota itu berasal dari Cirebon. Yang artinya, mereka harus menempuh perjalanan selama 4 jam setiap harinya demi satu kata: BERTAHAN. (Setia, 2020)

Sejarah waralaba Pizza Hut adalah perusahaan waralaba restoran pizza terbesar di dunia termasuk dalam hal jumlah outlet dan persentase pangsa pasar yang dimilikinya. Anak perusahaan dari PepsiCo, Inc ini memiliki lebih dari 11.000 outlet restoran pizza dan memiliki outlet pengiriman di lebih dari 90 negara di seluruh dunia. Pizza Hut didirikan pada tahun 1958 oleh 2 orang bersaudara, yaitu Dan dan Frank Carney di kampung halaman mereka di Wichita, Kansas. Ketika itu seorang teman menyarankan mereka untuk membuka kedai pizza dan akhirnya pun mereka setuju dan percaya jika ide tersebut akan berhasil. Istri Dan, Beverly, menyebutkan bahwa bangunan tempat mereka berjualan pizza seperti sebuah gubuk (Bahasa Inggris "Hut"). Akhirnya keputusan itupun dibuat. dan restoran pizza tersebut diberi nama Pizza Hut.(Ourstory, 2019)

Restoran pertama Pizza Hut di Indonesia dibuka pada tahun 1984, tepatnya di Gedung Djakarta Theatre, yang berada di daerah Thamrin, Jakarta Pusat. Kemudian restoran ini dipindahkan pada tahun 2000, masih ditetap area yang sama namun berbeda gedung, yaitu Gedung Cakrawala, yang bertahan hingga saat ini. Sekarang, Pizza Hut Indonesia memiliki lebih dari 200 gerai dan semuanya tersebar di 22 provinsi di wilayah Indonesia. (Ourstory, 2019)

\section{Rumusan masalah penelitian}

Dapat diformulasikan rumusan masalah penelitian ini yaitu: : "Bagaimanakah kontribusi strategi bertahan yang dilakukan oleh Pizza Hut Indonesia kepada pertumbuhan laba perusahaan?"

\section{Kegunaan penelitian}

Penelitian ini diharapkan dapat berguna bagi stakeholders baik secara teoretis maupun praktis dalam hal memilih dan menjalankan strategi bertahan agar dapat menyelamatkan perusahaan, khususnya di masa krisis.

\section{TINJAUAN EMPIRIS}

Dalam dunia usaha cukup mudah bagi pelaku usaha untuk memulainya. Hanya saja dalam mempertahankannya itulah yang cukup culit. Tapi, hal itu tidak akan terjadi apabila pelaku usaha mengetahui strategi khusus. Yakni strategi yang digunakan agar dapat bertahan dalam berbisnis. Berikut adalah 8 cara strategi bertahan dalam dunia bisnis dan usaha:

1. Menentukan merek dan positioning produk; merek dan positioning tersebut haruslah yang sesuai dengan target market dan dapat mewakili karakteristik dari barang yang diproduksi. Merek aksesori untuk remaja misalnya, tentunya harus dapat mewakili jiwa dan cita rasa remaja.

2. Menentukan lokasi penjualan; lokasi penjualan ditentukan oleh lokasi calon pembeli. Calon pembeli harus mudah mencapai lokasi penjualan sehingga strategi pemasaran dapat berjalan dengan baik.

3. Mendekati calon pembeli dengan perkenalan merek dan positioning produk; bisa dengan mengikuti event semacam bazaar, membuat website, menyebarkan flyers atau brosur, hingga membuat iklan dan memuatnya di media cetak maupun elektronik.

4. Membuat penawaran menarik; di bulan-bulan pertama sebaiknya dibuat beberapa penawaran yang dapat menarik minat calon pembali untuk mencoba menggunakan produk. Ubah penawaran pada waktu-waktu tertentu hingga posisi merek dan positioning kuat di benak calon pembeli. Saat merek dan positioning produk sudah mulai dikenal, bukan berarti keadaan sudah aman. Justru saat inilah kondisi mulai berbahaya karena pesaing pun sudah mulai mengenal merek perusahaan. Lalu apa yang harus perusahaan lakukan?

5. Network; memperluas jaringan dengan membuka hubungan. Misalnya dengan meminjamkan produk menjadi properti dalam majalah, mensponsori event yang sesuai dengan segmen konsumen, atau membuka lokasi penjualan baru. Dengan begitu, konsumen akan tambah mengenal produk perusahaan.

6. Mengembangkan usaha; Jika di awal pelaku usaha merintis usaha, segmentasi target market 
perusahaan adalah remaja, perusahaan boleh saja merambah ke segmen wanita dewasa. Selama jenis usaha dan jenis produknya tidak jauh berbeda, perusahaan tinggal menyesuaikan strategi marketing yang sudah ada.

7. Menguatkan hati, kerja keras dan pantang menyerah; menjalankan usaha sendiri tentunya cukup melelahkan, menyita waktu dan pikiran. Sementara orang lain memperoleh penghasilan tetap setiap bulan, pelaku usaha harus memikirkan berbagai pengeluaran. Inilah seni dari menjalankan usaha sendiri. Kuatkan hati, kerja keras dan pantang menyerah.

8. Nama merek usaha; jangan pernah memilih nama merek yang sama persis dengan nama merek lain yang telah ada. (Firmansyah, 2014)

Ada banyak strategi terbukti yang dapat diterapkan untuk terus menciptakan nilai tambah pada bisnis, bahkan ketika sumber daya perusahaan sangat terbatas, yaitu:

1. Sempurnakan strategi pemasaran perusahaan dan tingkatkan fokus pada taktik digital; pandemi telah mengajari sesuatu, saat ini kita lebih bergantung pada teknologi modern. Bahkan jika perusahaan tidak diposisikan untuk melakukan investasi besar dalam alat baru, maka harus terus mengevaluasi strategi dan teknologi digital yang sudah digunakan, dan sekarang adalah waktu yang tepat untuk melakukannya sebagai persiapan untuk "normal baru berikutnya". Tidak ada yang tahu bagaimana dunia akan berubah ketika Covid-19 akhirnya selesai. Namun, sangat mungkin bahwa banyak interaksi yang biasanya dilakukan secara langsung sebelum pandemi akan terus terjadi di lingkungan yang didominasi digital. Dengan pemikiran tersebut, mengembangkan keberadaan online yang kuat dan infrastruktur digital sekarang akan memberikan keuntungan di masa depan.

2. Meluncurkan produk atau layanan baru; di saatsaat seperti ini, perusahaan yang paling gesit biasanya adalah perusahaan yang unggul. Jika penjualan yang terkait dengan pendapatan utama mengalami penurunan selama pandemi, perusahaan harus menemukan aliran pendapatan baru. Strategi ini berlaku untuk pemula, bisnis kecil, dan bahkan konglomerat besar. Dengan mengambil pendekatan cekatan untuk pengembangan dan penjualan produk, merekmerek besar dapat tetap menjadi yang teratas di antara pelanggan mereka dan menunjukkan kualitas inovatif yang dicari konsumen modern dalam merek-merek terkemuka.

3. Menjalankan tanggung jawab sosial perusahaan; sebelum pandemi, para pemimpin bisnis dan pemasaran sudah mencari cara untuk memenuhi permintaan yang terus meningkat di antara konsumen dan investor untuk inisiatif tanggung jawab sosial perusahaan (CSR) yang jelas. Namun, legiatan CSR harus lebih dari sekadar taktik pemasaran. Konsumen menuntut orisinalitas — terutama generasi muda — dan untuk saat ini, dengan mendukung upaya bantuan Covid-19, baik dalam upaya lokal maupun global, sebuah brand akan menjadi lebih unggul. Laporan Tanggung Jawab Sosial Perusahaan Aflac 2019 menyatakan bahwa 77 persen konsumen lebih cenderung melakukan pembelian dari perusahaan yang berkomitmen untuk memerangi masalah sosial, ekonomi, dan lingkungan.

4. Mengarahkan bisnis selaras dengan kebutuhan pelanggan; meskipun perusahaan tidak menjual produk kesehatan, perusahaan memiliki banyak peluang untuk menciptakan interaksi yang bermakna dengan pelanggan di masa ini. Sebagai permulaan, perusahaan harus menjaga jalur komunikasi terbuka dan mengartikulasikan dengan jelas bagaimana bisnis perusahaan merespons dan beradaptasi dengan tantangan yang ditimbulkan oleh virus corona. Beri tahu pelanggan apa yang perusahaan lakukan untuk menjaga karyawan tetap aman dan apa yang perusahaan lakukan secara berbeda sekarang karena segala sesuatunya berbeda. Layanan pelanggan yang hebat selalu memisahkan perusahaan terbaik dari yang lain. Pada saat sebagian besar pemimpin cenderung mengalihkan fokus mereka ke dalam, pemimpin yang hebat akan melakukan segala upaya untuk memprioritaskan aspek-aspek pengalaman pelanggan yang terjadi jauh dari titik penjualan.

5. Mengutamakan kesejahteraan pekerja perusahaan; perusahaan yang tak terhitung jumlahnya telah dipaksa untuk memberhentikan staf, membatasi jam kerja, atau membuat keputusan keras lainnya untuk bertahan hidup. Mungkin perusahaan juga melewatinya, harus berusaha semaksimal mungkin untuk memastikan orang-orang yang terjebak bersama selama krisis tahu bahwa perusahaan menghargai mereka - dan ada banyak cara untuk melakukannya. Tim eksekutif di Best Buy, misalnya, menyediakan layanan kesehatan mental gratis kepada anggota staf yang tiba-tiba merasa kewalahan di tengah ketidakpastian yang belum pernah terjadi sebelumnya. Terlepas dari bagaimana perusahaan melakukannya, mengutamakan karyawan sekarang dapat membantu menumbuhkan budaya perusahaan 
yang diperkuat oleh kesulitan, daripada budaya yang layu ketika keadaan menjadi sulit. Pada tahun 2020, bisnis telah belajar bahwa penciptaan nilai memerlukan lebih dari sekadar memenuhi kebutuhan pasar. Ini adalah produk dari aksi korporasi yang memengaruhi karyawan, pelanggan, dan semua pemangku kepentingan lainnya. Semakin banyak nilai di area yang peruashaan buat hari ini, semakin mudah untuk terus membuatnya besok. (Aninda, 2020)

Penelitian Susilo menerangkan bahwa strategi bertahan yang diterapkan oleh responden adalah dengan menaikkan harga produk dan atau dilakukan dengan menerapkan strategi bertahan yang lain. Strategi bertahan yang lain adalah dengan menerapkan harga yang tetap atau tidak berubah dan atau diterapkan dengan strategi bertahan yang lain. Hasil survei menunjukkan bahwa sebagian besar responden yaitu $86 \%$ menerapkan strategi menaikkan harga produk, sisanya sebanyak $14 \%$ mengaku tidak menaikkan produk. Berbagai macam strategi bertahan yang diterapkan oleh responden pada dasarnya ditujukan agar usahanya tetap dapat beroperasi atau berproduksi. (Susilo, 2018)

Hasil penelitian yang dilakukan oleh Okta dan Nanang menunjukkan 15 dari 100 perusahaan cenderung melakukan diversifikasi usaha selama pandemi Covid-19. Tiga sektor yang perusahaannya paling banyak melakukan diversifikasi usaha adalah industri pengolahan penyediaan akomodasi, makanan maupun minuman, perdangan reparasi kendaraan. Perusahaan juga menerapkan protokol kesehatan untuk adaptasi kebiasaan baru di lingkungan kerja, penerapan protokol meliputi penerapan physical distancing, menyediakan sarana sinitasi, penerapan wajib masker. Berbagai macam strategi yang bisa di lakukan perusahaan untuk bertahan di masa pandemi selain diversifikasi adalah dengan menerapkan e-commerce dan digital marketing untuk pemasaran produk perusahaan. Berbagai strategi dilakukan perusahaan dilakukan dalam uapaya mempertahankan perusahaan di masa pandemi Covid-19. (Okta \& Nanang, 2020)

Rosmadi melakukan penelitian yang dilakukan pada usaha kecil diketahui bahwa untuk keberlangsungan usahanya Waroenk Ngemil berupaya untuk memasarkan produk makanannya secara optimal. Strategi pemasaran yang digunakan di tengah pandemi Covid-19 yaitu dengan menggunakan media sosial antara lain, Facebook, Instagram, Whatsapp, Telegram, serta tergabung dalam usaha online lainnya seperti Shopee, Go-food, dan Grab-food. Dapat disimpulkan bahwa untuk mempertahankan kelangsungan usaha kecil
(UMKM) pemanfaatan internet dan media sosial merupakan strategi yang sangat tepat di tengah pandemi Covid-19 ini. Namun demikian penggunaan teknologi juga membutuhkan biaya yang tidak sedikit serta sumber daya manusia yang memiliki kemampuan di bidang teknologi informasi. Bagi peneliti selanjutnya hendaknya menggunakan metode penelitian lain agar hasil yang diperoleh lebih signifikan. (Rosmadi, 2021)

Penelitian dari Saul dan Susilo menyatakan bahwa strategi bersaing pada usaha mikro kecil bakpia pathok Kampung Purwodiningratan, Yogyakarta yang dilakukan agar dapat terus bertahan dalam menjalankan usahanya adalah:

1. Dilakukan pengenalan produk bakpia dengan cara promosi lewat tetangga, menitipkan di toko bakpia terdekat dan internet.

2. Agar tetap bersaing dengan produsen lain, produsen memilih peningkatan kualitas karena mereka tidak ingin mengecewakan konsumen.

3. Dari segi tenaga kerja, terlalu sedikit tenaga kerja yang digunakan oleh produsen sehingga dalam memproduksi bakpia kurang efektif. Seharusnya tenaga kerja yang digunakan perlu ditingkatkan apabila dalam memproduksi bakpia kurang cepat. (Saul \& Susilo, 2015)

\section{METODE PENELITIAN Unit analisis penelitian}

Adapun yang digunakan sebagai unit analisis dalam penelitian ini ialah PT Sarimelati Kencana, Tbk selaku pemegang warabala restoran cepat saji Pizza Hut Indonesia.

\section{Jenis penelitian}

Penelitian ini dilakukan dengan menggunakan jenis penelitian deskriptif kuantitatif, yaitu penelitian yang berusaha memperlihatkan hasil dari suatu pengumpulan data kuantitatif atau statistik seperti survei dengan apa adanya, tanpa dihitung atau dilihat hubungannya dengan perlakuan atau variabel lain. Metode ini digunakan untuk menggambarkan, menjelaskan, atau meringkaskan berbagai kondisi, situasi, fenomena, atau berbagai variabel penelitian menurut kejadian sebagaimana adanya yang dapat dipotret, diwawancara, diobservasi, serta yang dapat diungkapkan melalui bahan-bahan dokumenter.

\section{Teknik Analisis Data}

Untuk menjawab pertanyaan penelitian digunakan teknik analisis data secara kualitatif yang mengikuti tiga tahapan berikut ini:

Analisis data; melakukan analisis terhadap data yang telah didapatkan, peneliti dalam hal ini bisa 
melakukan interpretasi dari data yang didapatkan dilapangan.

Mengambil kesimpulan dan verifikasi; dari kegiatan-kegiatan sebelumnya, langkah selanjutnya adalah menyimpulkan dan melakukan verifikasi atau kritik sumber apakah data tersebut valid atau tidak.

Narasi hasil analisis; langkah terakhir adalah pelaporan hasil penelitian dalam bentuk tulisan dan biasanya pendekatan kualitatif lebih cenderung menggunakan metode deskriptif-analitis.

\section{HASIL PENELITIAN DAN PEMBAHASAN}

Untuk melihat efek strategi bertahan di masa pandemic Covid-19 yang sudah dijalankan oleh Pizza Hut Indonesia dapat dianalisis dari capaian keuangan khususnya laporan laba rugi. Berdasarkan laporan keuangan periode Januari sampai dengan September 2020 PT Sarimelati Kencana, Tbk selaku pemegang waralaba restoran Pizza Hut Indonesia yang diunduh dari situs emiten.kontan.co.id (Kontan.co.id, 2020), didapatkan fakta-fakta keuangan sebagai berikut:

1. Penjualan bersih periode Januari-Juni sebesar Rp1.818.354.492.134. Penjualan bersih periode Juli-September sebesar Rp847.327.286.548. Artinya, strategi bertahan yang dilakukan Pizza Hut Indonesia masih bisa mencetak penjualan bersih positif walaupun berada pada kondisi pandemi Covid-19.

2. Harga Pokok Penjualan periode Januari-Juni sebesar Rp634.659.672.456. Harga Pokok Penjualan periode Juli-September sebesar Rp293.198.983.657. Artinya, strategi bertahan yang dilakukan Pizza Hut Indonesia masih bisa melakukan produksi positif walaupun berada pada kondisi pandemi Covid-19.

3. Laba bruto periode Januari-Juni sebesar Rp1.183.694.819.678. Laba bruto periode JuniSeptember sebesar Rp554.128.302.891. Artinya, strategi bertahan yang dilakukan Pizza Hut Indonesia masih bisa mencetak laba bruto positif walaupun berada pada kondisi pandemi Covid19.

4. Laba operasi periode Januari-Juni sebesar Rp26.786.334.586 dengan beban operasional sebesar Rp 1.156.908.485.092. Laba operasi periode Juni-September sebesar -Rp13.663.222.221 dengan beban operasional sebesar Rp 567.791.525.112. Artinya, strategi bertahan yang dilakukan Pizza Hut Indonesia masih bisa mencetak laba operasi positif dan masih bisa menjaga stabilisasi beban operasional walaupun berada pada kondisi pandemi Covid19.

5. Laba sebelum beban pajak periode Januari-Juni sebesar Rp 15.925.809.653 dengan beban bunga dan keuangan sebesar Rp 12.248.254.329. Laba sebelum beban pajak periode Juli-September sebesar -Rp 7.089.773.401 atau rugi dengan beban bunga dan keuangan sebesar Rp 21.819.961.175. Artinya, Pizza Hut Indonesia mengalami kerugian pada periode JuliSeptember disebabkan oleh beban bunga dan keuangan yang jumlahnya melebihi laba operasi yang diperoleh pada periode tersebut.

\section{SIMPULAN DAN SARAN}

Dapat disimpulkan bahwa strategi bertahan yang dilakukan oleh PT Sarimelati Kencana, Tbk dalam menghadapi kondisi pandemi Covid-19 sudah tepat, karena terbukti strategi tersebut masih bisa mencetak penjualan yang positif, harga pokok penjualan yang stabil, laba bruto yang masih positif, laba operasi yang masih positif, dan beban operasional yang masih stabil. Tetapi beban bunga dan keuangan yang jumlahnya melebihi laba operasi menjadi penyebab kerugian bagi perusahaan pemegang waralaba restoran Pizza Hut Indonesia tersebut.

Dari penelitian ini dapat disarankan untuk pelaku bisnis pada umumnya agar mempertimbangkan dan memperhatikan secara prudent terhadap rencana atau keputusan berutang. Apabila pelaku usaha sudah terlanjur berutang, maka kuatkan niat dan tekad untuk segera melunasi utangutang tersebut. Produk yang bagus, harga jual produk yang bagus, promosi yang efektif, lokasi berjualan yang strategis, serta volume penjualan yang meningkat akan menjadi sia-sia ketika pelaku usaha dihadapkan pada beban bunga utang yang jumlahnya melebih laba operasi.

\section{DAFTAR PUSTAKA}

Aninda, N. (2020). 5 Strategi Bisnis Untuk Bertahan Saat Pandemi - Entrepreneur Bisnis.com. Retrieved July 13, 2021, from https://entrepreneur.bisnis.com/read/2020101 9/88/1307125/5-strategi-bisnis-untukbertahan-saat-pandemi

Firmansyah, M. (2014). Strategi Bertahan dalam Berbisnis Halaman all - Kompasiana.com. Retrieved July 13, 2021, from https://www.kompasiana.com/mohammadfir mansyah/54f93688a33311f8478b4cf2/strategi -bertahan-dalam-berbisnis?page=all\#section 1

Fitria, R. (2020). Bertahan di Tengah Pandemi COVID-19, Gerai Pizza Ini Jualan di Pinggir Jalan. Retrieved July 12, 2021, from detikfood website: https://food.detik.com/info-kuliner/d5024728/bertahan-di-tengah-pandemi-covid- 
19-gerai-pizza-ini-jualan-di-pinggir-jalan

Ishak. (2020). PROMO Pizza Hut Juni 2020 Terbaru,

4 Kotak Menu Pizza Hut Terbaru Funt4stic

Box Cuma Rp 100 Ribu - Halaman 3 - Tribun Pontianak. Retrieved July 12, 2021, from https://pontianak.tribunnews.com/2020/06/20/ promo-pizza-hut-juni-2020-terbaru-4-kotakmenu-pizza-hut-terbaru-funt4stic-box-cumarp-100-ribu?page=3

Junior, S. (2020). FOTO: Pizza Hut Jualan di Pinggir Jalan - Tribun Timur. Retrieved July 12, 2021, from

https://makassar.tribunnews.com/2020/05/19/ foto-pizza-hut-jualan-di-pinggir-jalan

Kontan.co.id. (2020). Laporan Keuangan PT Sarimelati Kencana Tbk. (PZZA) Kinerjaemiten.com. Retrieved July 13, 2021, from https://emiten.kontan.co.id/perusahaan/614/P T-Sarimelati-Kencana-Tbk

Nurhadi, M. (2020). Viral Karyawan Pizza Hut Jualan di Pinggir Jalanan Jogja, Netizen: Salut! - Suara Jogja. Retrieved July 12, 2021, from suarajogja.id website: https://jogja.suara.com/read/2020/05/27/1300 39/viral-karyawan-pizza-hut-jualan-dipinggir-jalanan-jogja-netizen-salut

Okta, E., \& Nanang, V. (2020). Strategi Bertahan Perusahaan di masa Pandemi Covid-19 PENDAHULUAN Pandemi covid-19 menyebabkan diterapkannya pembatasan sosial berskala besar ( PSBB ) dan kebijakan bahkan pemberlakuan lockdown di berbagai negara tak terkecuali di Indonesia . PSBB ini ber. PROCEEDING SEMINAR NASIONAL PENALARAN DAN PENELITIAN NUSANTARA 2020, 1(1), 160-168. Retrieved from

https://proceeding.unpkediri.ac.id/index.php/p pn

Ourstory. (2019). Sejarah Waralaba Pizza Hut, Waralaba Pizza Terbesar - Ourstory.id. Retrieved July 13, 2021, from https://ourstory.id/sejarah-waralaba-pizzahut-waralaba-pizza-terbesar/

Rosmadi, M. L. N. (2021). Penerapan Strategi Bisnis di Masa Pandemi Covid-19 Jurnal IKRA-ITH Ekonomika Vol 4 No 1 Bulan Maret 2021. Jurnal IKRA-ITH Ekonomika, 4(1), 122-127. Retrieved from https://journals.upiyai.ac.id/index.php/IKRAITHEKONOMIKA/issue/view/59

Saul, E. Y., \& Susilo, Y. S. (2015). Strategi Bersaing Dan Strategi Bertahan Pada Industri Mikro Dan Kecil Bakpia Pathok Di Kecamatan Ngampilan Yogyakarta. Journal of Chemical Information and Modeling, 53(9), 1689-1699. Retrieved from https://core.ac.uk/download/pdf/35392233.pd $\mathrm{f}$

Setia, D. A. (2020). 'Promo Pandemi' Pizza Hut Menuai Simpati, Netizen Terinspirasi untuk Lebih Kreatif di Masa Krisis - Portal Jember Halaman 2. Retrieved July 12, 2021, from https://portaljember.pikiranrakyat.com/nasional/pr-16649450/promopandemi-pizza-hut-menuai-simpati-netizenterinspirasi-untuk-lebih-kreatif-di-masakrisis?page $=2$

Susilo, Y. S. (2018). Strategi Bertahan Industri Makanan Skala Kecil Pasca Kenaikan Harga Pangan Dan Energi Di Kota Yogyakarta. EKUITAS (Jurnal Ekonomi Dan Keuangan), 14(2), 225-244. https://doi.org/10.24034/j25485024.y2010.v1 4.i2.284 